\title{
Overview of large building testing in Baltic countries
}

\author{
Andrejs Nitijevskis ${ }^{1, *}$, Vladislavs Keviss ${ }^{2}$ \\ ${ }^{1}$ IRBEST Ltd, 84-133, Kurzemes pr., Riga, Latvia, LV-1067. \\ ${ }^{2}$ IRBEST Ltd, 84-133, Kurzemes pr., Riga, Latvia, LV-1067.
}

\begin{abstract}
The objectives of this paper are to review measurements of airtightness of 2 large building groups - middle size shops, and warehouses/distribution centres. The mean air leakage rate at $50 \mathrm{~Pa}$ pressure difference $\mathrm{q}_{50}$ was $1.04 \mathrm{~m}^{3} / \mathrm{m}^{2} \mathrm{~h}$ and $1.35 \mathrm{~m}^{3} / \mathrm{m}^{2} \mathrm{~h}$ for shops and warehouses respectively. Analysis of measurement results is valuable because it allows to make a conclusion about compliance of national and corporative construction airtightness norms with actual air barrier condition on a comissioning stage. In the concluding part of the study there are suggested ways to improve air barrier such as review of construction norms, implementation of a mandatory testing and quality control of a measurement.
\end{abstract}

\section{Introduction}

Due to the increase of thermal insulation properties of construction materials and the decrease of the part of heat conductivity losses the part of air filtration losses through discontinued or broken air barrier has increased significantly. Moreover, increased insulation thickness is not reasonable from economic point of view.

According to the simulations by Jokisalo and Kurnitski [6], air tightness has a significant effect on the heat energy consumption. The increase of the heat energy use due to infiltration is about 15 to $30 \%$. Therefore the improved air barrier allows not only to decrease carbon dioxide emission $(0.264 \mathrm{kgCO} 2 / \mathrm{kWh})$, but to solve the followng issues for the property owner and tenants:

- inner climate gain.

- prevention of the damage of construction parts and joints due to condensation.

- prevention of poluttants and particles penetration into machinery and on a production surface. It is actual for internet retail sorting and distribution centres.

The experience from large buildings testing has shown the main conditions to control air barrier quality:

- Building design, e.g. selecting airtight materials and avoiding unnecessary penetrations

- Workmanship quality

- Supervision

Due to the subjective character of the above mentioned conditions it is hardly possible to predict air barrier qualitative value. The most effective way to evaluate airtightness of a building envelope air barrier is to carry out a measurement along with air leakage path locating. Herewith this procedure is the most essential for large buildings (volume greater than 4,000 $\mathrm{m}^{3}$ according to EN13829-2000 p.5.3.4.a. definition) due to the following reasons:

- Stack effect and wind have a greater impact on a building envelope and consequently on a energy consumption, HVAC and BMS systems.

\footnotetext{
* Corresponding author: Andrejs Nitijevskis, $\underline{\text { irbest } @ \text {,irbest.lv }}$
}

- Ratio of labour costs, time and costs of testing to volume of a building or to an envelope area is much lower than for small buildings;

- Losses and harm due to increased air leakage in absolute figures for large buildings are much higher than for small buildings, which makes Blower Door technology an effective tool of energy saving just for large buildings.

\section{Methods}

\subsection{Measurement methods}

All the measurements were carried out in accordance with international standards EN13829-2000 (building preparation method B) [1]. and ISO9972-2015 (method 2) [2]. According to the methods of preparation all the intentional openings of building envelope shall be sealed, the doors, windows and trapdoors being closed. Measurements of airtightness were carried out by blower door systems EU3000 and EU6000 with 14,000 m³ flow at $50 \mathrm{~Pa}$ (Woehler Retrotec Inc., USA). A quantity of systems varied from 1 to 27 pcs. of fans depend on required flow to fulfill national or corporate construction norms for airtigtness, Fig.1.

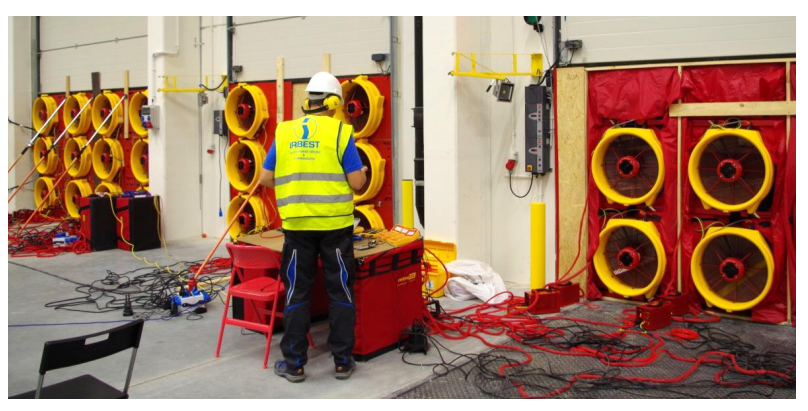

Fig.1. Setup of 24 pcs of EU3000 High-Power fans 
FanTestic software (Retrotec Inc.) was used for data collection, calculation and evaluation according to EN13829-2000 and ISO9972-2015 standards.

\subsection{Leak location procedure}

Despite the measurement results there was performed leak location test with thermal imaging camera and/or smoke machine. A leak location by thermal imaging camera FLIR T460 with sensivity $0,03{ }^{\circ} \mathrm{C}$ was carried out under pressure and temperature differences according to p.6.2 cof EN13187-1998 standard [3], Fig. 2 and Fig. 3.
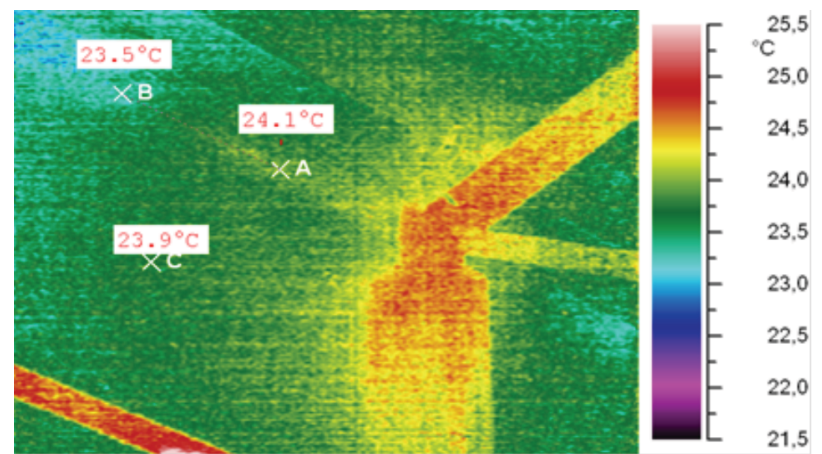

Fig.2. An example of leak location at $\Delta \mathrm{P}<5 \mathrm{~Pa}, \Delta \mathrm{T}=6{ }^{\circ} \mathrm{C}$. Joints of ceiling with external wall.

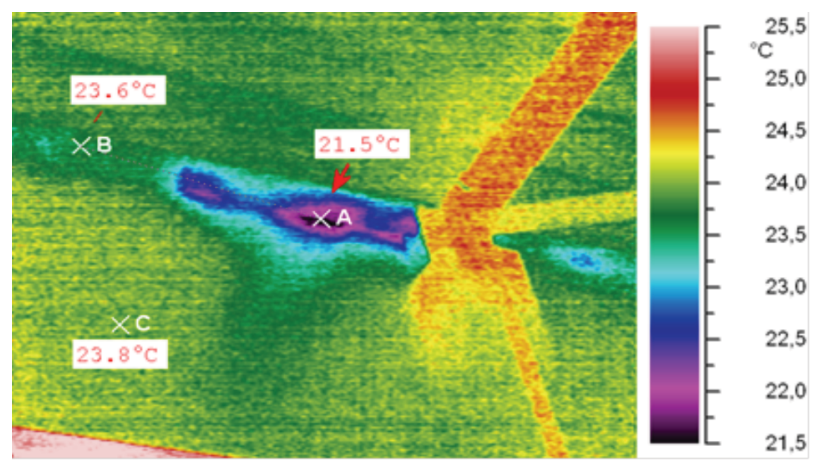

Fig.3. An example of leak location at $\Delta \mathrm{P}=-30 \mathrm{~Pa}, \Delta \mathrm{T}=6{ }^{\circ} \mathrm{C}$. Joints of ceiling with external wall.

Additionally to thermal camera for leak location were used theatrical machine Power-TINY (LookSolution), Fig.4, and thermoanemometer KIMO-VT150.

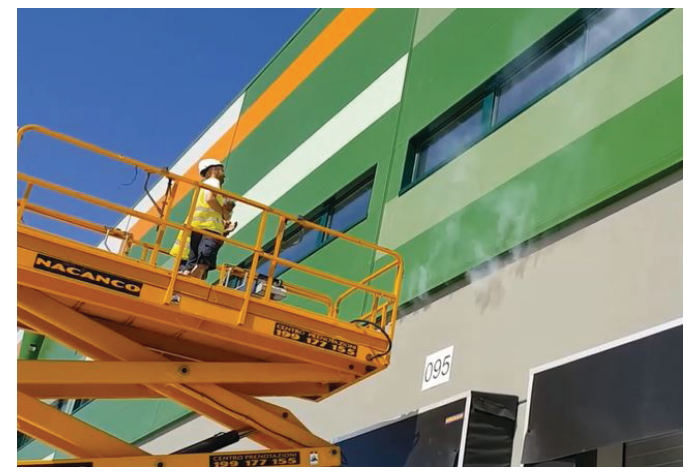

Fig.4. An example of leak location with theatrical smoke under overpressure $\triangle \mathrm{P}=30 \mathrm{~Pa}$
The main sources of airfiltration were:

- Joints of ceiling with external wall.

- Joints of different parts of wall (e.g. block part and panels).

- Gates.

- Movable loading bridges.

- Electrical and ventilation duct crossing air barrier of ceiling and wall.

\section{Results}

A protocol and an air leak location report were handed to a customer upon a test execution. Measured results were expressed by the average air leakage $\left(\mathrm{q}_{50}, \mathrm{~m}^{3} / \mathrm{m}^{2} \mathrm{~h}\right)$ at a pressure difference of $+/-50 \mathrm{~Pa}$ and by air change per hour $\left(\mathrm{n}_{50}, \mathrm{~h}^{-1}\right)$ at $+/-50 \mathrm{~Pa}$, Table 1. Fig. 5,6.

Table 1. Results of airtightness measurements

\begin{tabular}{|l|c|c|c|}
\hline \multicolumn{2}{|c|}{ Type of building } & Shop & Warehouse \\
\hline \multicolumn{2}{|c|}{ Number of buildings } & 32 & 41 \\
\hline \multirow{2}{*}{$\begin{array}{l}\text { air leakage q50, } \\
\left(\mathrm{m}^{3} / \mathrm{m}^{2} \mathrm{~h}\right)\end{array}$} & Average & 1.04 & 1.35 \\
\cline { 2 - 4 } & St.dev & 0.37 & 0.52 \\
\hline \multirow{2}{*}{$\begin{array}{l}\text { air change rate } \\
\left(\mathrm{n}_{50}, \mathrm{~h}^{-1}\right)\end{array}$} & Average & 0.46 & 0.25 \\
\cline { 2 - 4 } & St.dev & 0.18 & 0.11 \\
\hline
\end{tabular}

\section{Air leakage rate $q_{50}, \mathrm{~m}^{3} / \mathrm{m}^{2} \mathrm{~h}$ \\ Measured air leakage rate \\ - $\quad$ LBN 002-19 (Latvia) \\ - Estonia* \\ - $\quad$ BREEAM, DGNB}

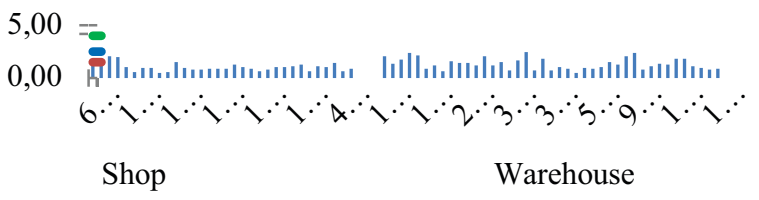

Fig.5. Distribution of the results of air leakage $\mathrm{q}_{50},\left(\mathrm{~m}^{3} / \mathrm{m}^{2} \mathrm{~h}\right)$ 口

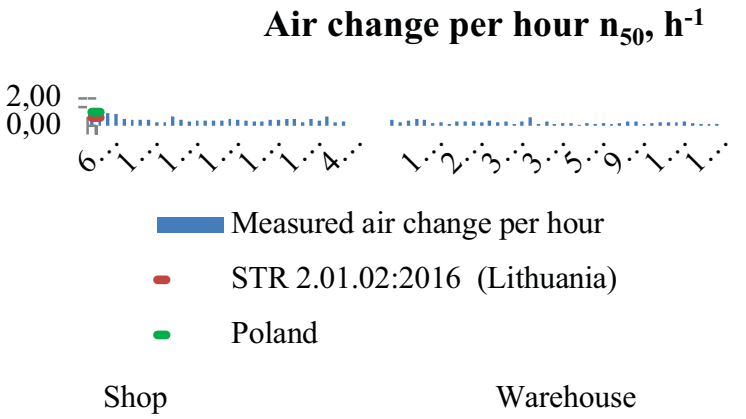

Fig.6. Distribution of the results of air change rate $\left(\mathrm{n}_{50}, \mathrm{~h}^{-1}\right)$ 
In the most cases a measurement result was positive, therefore, a retest was not carried out unless it was required by a customer due to a negative leak location report.

In the measured middle size buildings $\left(6,000 \mathrm{~m}^{3}\right.$ $\left.50,000 \mathrm{~m}^{3}\right)$ the air leakage $\mathrm{q}_{50}$ being varied from minimum $0.46 \mathrm{~m}^{3} / \mathrm{m}^{2} \mathrm{~h}$ to maximum $2.06 \mathrm{~m}^{3} / \mathrm{m}^{2} \mathrm{~h}$ with mean $1.04 \mathrm{~m}^{3} / \mathrm{m}^{2} \mathrm{~h}$. The mean air change rate ACH was $0.46 \mathrm{~h}^{-1}$, minimum $0.25 \mathrm{~h}^{-1}$ and maximum $0.92 \mathrm{~h}^{-1}$.

In the measured large size buildings $\left(100,000 \mathrm{~m}^{3}-\right.$ $1,500,000 \mathrm{~m}^{3}$ ) the air leakage $\mathrm{q}_{50}$ being varied in a range of 0.52 to $2.47 \mathrm{~m}^{3} / \mathrm{m}^{2} \mathrm{~h}$ with a mean value of 1.35 $\mathrm{m}^{3} / \mathrm{m}^{2} \mathrm{~h}$. The mean air change rate $\mathrm{ACH}$ was $0.25 \mathrm{~h}^{-1}$, minimum $0.10 \mathrm{~h}^{-1}$ and maximum $0.60 \mathrm{~h}^{-1}$.

The results of the both groups of buildings cleary show:

- Measured ACH $0.25 \mathrm{~h}^{-1}$ of large size buildings significantly lower than ACH $0.46 \mathrm{~h}^{-1}$ of middle size buildings but mean air leakages $\mathrm{q}_{50}$ do not demonstrate such rate of difference due to different compactness. This statement earlier was claimed in Paul Simons and Stefanie Rolfsmeier study [4].

- Mean air leakage $1.04 \mathrm{~m}^{3} / \mathrm{m}^{2} \mathrm{~h}$ for middle size building explained by corporative and national norms $\mathrm{q}_{50}<1.5 \mathrm{~m}^{3} / \mathrm{m}^{2} \mathrm{~h}$ for studied group of buildings.

- Air leakage rate $\mathrm{q}_{50}$ is objective and is applicable for a wide range of building volume. This fact is also confirmed by using of $\mathrm{q}_{50}$ in the most countries with mandatory testing of airtightness (except e.g. Lithuania).

- Measured air leakage rate $\mathrm{q}_{50}$ and $\mathrm{ACH} \mathrm{n}_{50}$ has demonstrated a result much better than required by national or corporate standards. Obviously the most construction norms were developed without considering large building measurement data. It explains the lack of motivation and control function among majority of national, corporate and ,green" construction norms in the field of envelope airtightness. In our experience there were cases of changes of national and corporate constuction norms based on measerument results analysis, e.g. gain of air leakage rate value up to $\mathrm{q}_{50}<1.0 \mathrm{~m}^{3} / \mathrm{m}^{2} \mathrm{~h}$. The latest tests clearly show efficiency of the new value as filter.

Comparison of measured air leakage rate and lodgement statistic published by Air Tightness Testing \& Measurement Association, UK ((https://www.bcta.group/attma/lodgement-statistics-airtightness/) for non-dwellings ( $\mathrm{q}_{50}=4.95 \mathrm{~m}^{3} / \mathrm{m}^{2} \mathrm{~h}$ and higher) clearly shows impact of national construction norms on real airtightness of building envelope.

It is worth pointing out that a floor as a most airtightness part of a building envelope has a significant percentage of total area for buildings like warehouse (volume $100000 \mathrm{~m}^{3}$ and height $12-15 \mathrm{~m}$ ) and is included in air leakage rate calculation. A better $\mathrm{q}_{50}$ value could be achieved than for smaller buildings with the similar airtightness of the rest envelope parts (walls and ceiling). But fairly often there are movable loading bridges installed in the floor surface and have a gap.
Therefore, the floor surface can not be considered as airtight and misrepresented measurement result. Anyway this topic is to be discussed.

\section{Conclusion}

Testing experience and large building measurement results of leakage rate $\mathrm{q}_{50}$ with volume up to $1,500,000$ $\mathrm{m}^{3}$ allow to come to the following conclusions:

- Airtightness improvement of building air barrier is an efficient way of reduction of carbon dioxide emission and energy demand of building.

- Voluntary testing and current construction norms, which in the most countries are significantly lower than actual air leakage values of building envelope, do not fulfill functions to control and motivate construction quality.

- Air change rate $\mathrm{n}_{50}$ does not allow to compare a quality of the building envelope of buildings of wide volume and compactness range. This statement earlier was claimed in AIRAH study [5].

- Large volume of building is not a reason to avoid testing because it is necessary to provide smaller flow than it is required by wrong construction norms.

- Testing allows to make satisfactory conditions for air barrier quality assessment by thermal imaging camera and smoke machine.

There are the following parts of airtightness measurement technolgy success:

- Reasonable construction norms and standards of measurement

- Mandatory of testing

- Quality assurance system of test providers.

Possible options for technology implementation:

- Mandatory test

- Random test

- Test of certain group of building, e.g. Near Zero Energy Building or A++ energy performance class.

\section{References}

1. LVS EN 13829-2000. Thermal performance of buildings-determination of air permeability of buildings-fan pressurization method. 2001

2. LVS EN ISO 9972-2015. Thermal performance of buildings determination of air permeability of buildings.fan pressurization method.2015

3. LVS EN 13187. Thermal Performance of Buildings - Qualitative Detection of Thermal Irregularities in Building Envelopes - Infrared Method.1998

4. Postulate for airtightness limits in large buildings. Paul Simons and Stefanie Rolfsmeier, 33rd AIVC Conference, Copenhagen, Denmark, 10-11 October 2012

5. Air Tightness Metrics to Improve Australian Housing Envelope Integrity. Australian Institute of 
Refrigeration Air Conditioning and Heating (AIRAH). November, 2017

6. Jokisalu J, Kurnitski J. Simulation of energy consumption in typical Finnish detached house. Helsinki University of Technology,

HVAClaboratory, Report B74; 2002. 